\title{
Nailfold video capillaroscopy in Turner syndrome: a descriptive study
}

\author{
Videocapilaroscopia na síndrome de Turner: estudo descritivo
}

\author{
Simone C. S. Coelho, ${ }^{1}$ Andressa D. Ramos, ${ }^{1}$ Virgínia S. Pinheiro, ${ }^{1}$ Paulo F. C. Solberg, ${ }^{1}$ \\ Janaina P. de Faria, ${ }^{2}$ Erika C. O. Naliato, ${ }^{1}$ Therezinha J. Fernandes, ${ }^{3}$ Marília M. Guimarães ${ }^{4}$
}

\begin{abstract}
Background: An increased prevalence of impaired glucose homeostasis is reported in Turner syndrome. Endothelial changes are described in patients with insulin resistance, which may be present in patients with Turner syndrome. Video capillaroscopy is a noninvasive examination that allows assessment of vascular patency.
\end{abstract}

Objective: To describe the nailfold morphology of capillaries in Turner syndrome using video capillaroscopy.

Methods: Subjects were studied in a temperature-controlled room, 20 days after no nailfold manipulations. The capillaries were visualized by microscope connected to a television and computer and were studied and classified according to these patterns: loop distribution, papilla, avascular fields, edema, form, capillary limbs, flow and hemorrhagic extravasation.

Results: Fifty patients aged between 6-37 years with Turner syndrome were studied. Eighteen $(36 \%)$ patients had normal capillaroscopy with hairpin pattern in loop distribution and no avascular fields. The papilla was ratified in $13(26 \%)$ and enlarged in four $(8 \%)$. Edema occurred in $22(44 \%)$ cases. There were three $(6 \%)$ macrocapillaries and three $(6 \%)$ were branched. Tortuosity was present in five $(10 \%)$ patients. Hemorrhagic extravasation occurred in one $(2 \%)$ case. Flow was fast in seven (14\%), granulous in five $(10 \%)$ and slow in $\operatorname{six}(12 \%)$.

Conclusion: There was a high prevalence of nailfold capillaroscopy changes in Turner syndrome and the most prevalent alterations found were edema and ratified papilla.

Keywords: Turner syndrome, nailfold capillaroscopy, endothelium.

\section{Introduction}

Turner syndrome (TS) is a relatively common chromosome disorder, caused by complete or partial X monosomy. TS affects approximately 1:2,000 female births and as many as $10 \%$ of spontaneous miscarriages have a 45,X karyotype. ${ }^{1,2}$ Gonadal dysgenesis and short

\section{Resumo}

Contexto: Estudos evidenciam distúrbios no metabolismo da glicose na síndrome de Turner. As alterações no endotélio estão descritas em pacientes com resistência insulínica, que pode ocorrer em pacientes com síndrome de Turner, e o estudo dos capilares pela videocapilaroscopia é um exame não-invasivo que permite avaliação da permeabilidade vascular.

Objetivo: Descrever a morfologia dos capilares na síndrome de Turner usando a videocapilaroscopia.

Método: As pacientes foram estudadas em sala com temperatura controlada, após 20 dias sem manipulação das cutículas. Os capilares foram visualizados por microscópio conectado à televisão e computador, sendo estudados de acordo com os seguintes parâmetros: distribuição de alças, papila, praias desertas, edema, forma, tamanho, fluxo e hemorragia.

Resultados: Cinqüenta pacientes com síndrome de Turner foram estudadas, com idades entre 6 e 37 anos. Dezoito (36\%) tiveram exame normal com distribuição de alças com padrão em paliçada e sem praias desertas. A papila foi retificada em $13(26 \%)$ e alargada em quatro $(8 \%)$. Edema ocorreu em $22(44 \%)$ casos. Havia três $(6 \%)$ capilares ectasiados e três $(6 \%)$ eram ramificados. Tortuosidade estava presente em cinco $(10 \%)$ pacientes. Hemorragia ocorreu em um $(2 \%)$ caso. O fluxo foi rápido em sete $(14 \%)$, granuloso em cinco $(10 \%)$ e lento em seis $(12 \%)$.

Conclusão: Houve uma maior prevalência de anormalidades na videocapilaroscopia na síndrome de Turner, e as alterações mais comuns foram edema e papila retificada.

Palavras-chave: Síndrome de Turner, videocapilaroscopia, endotélio.

stature are two of the characteristic clinical features of this syndrome. ${ }^{1-6}$

An increased prevalence of impaired glucose homeostasis and diabetes mellitus is reported in TS. ${ }^{7-10}$ Insulin resistance appears very early in the natural history of TS. ${ }^{10-14}$ This resistance seems to involve monoxidative

1. Graduate Program in Endocrinology, School of Medicine, Hospital Universitário Clementino Fraga Filho (HUCFF), Universidade Federal do Rio de Janeiro (UFRJ), Rio de Janeiro, RJ, Brazil.

2. Graduate Program of Nutrology, School of Medicine, HUCFF, UFRJ, Rio de Janeiro, RJ, Brazil.

3. Angiology Department, HUCFF, UFRJ, Rio de Janeiro, RJ, Brazil.

4. Endocrinology Department, HUCFF, UFRJ, Rio de Janeiro, RJ, Brazil.

Manuscript received Sep 16 2007, accepted for publication Oct 292007.

J Vasc Bras. 2007;6(4):325-331.

Copyright $\odot 2007$ by Sociedade Brasileira de Angiologia e de Cirurgia Vascular 
Table 1 - Distribution of groups by karyotype and pubertal status

\begin{tabular}{lccc}
\hline Variable & Group 1 (n= 18) & Group 2 (n= 32) & Total $(\mathbf{n}=\mathbf{5 0})$ \\
\hline Karyotype & & & \\
45,X & $11(61.1 \%)$ & $16(50 \%)$ & 27 \\
Mosaicism & $7(38.9 \%)$ & $16(50 \%)$ & 23 \\
Pubertal development & & & \\
Prepubertal & $5(27.8 \%)$ & $11(34.3 \%)$ & 16 \\
Spontaneous puberty & $1(5.5 \%)$ & $5(15.6 \%)$ & 6 \\
Postpubertal & $13(72.2 \%)$ & $21(65.7 \%)$ & 34 \\
\hline
\end{tabular}

pathways of glucose metabolism and is likely to predispose adults with TS to future development of diabetes. ${ }^{3-5}$

Endothelial disturbance is present in groups with increased risk for diabetes and insulin resistance. ${ }^{12-17}$ Human microcirculation can be studied in vivo using different methods, such as plethysmography and capillaroscopy. ${ }^{17-23}$

The aim of this study is to describe the morphology of nailfold capillaries in patients with TS using videocapillaroscopy.

\section{Methods}

A descriptive cross-sectional study was carried out. Diagnosis of ST was confirmed by karyotype. Diabetic patients were excluded. This study was approved by the ethics committee of Universidade Federal do Rio de Janeiro. Subjects were studied in a temperature-controlled room in the morning following a night's fasting, 20 days after no nailfold manipulations. The subjects were comfortably seated in a chair with the observed hand at heart level with the forearm and hand bent at the elbow. All patients had their arm blood pressure measured in this position using the auscultatory method. Capillaries were visualized by microscope connected to a television monitor and computer. A few drops of immersion oil were spread on the observation area. Capillary morphology was studied in a magnification of 0.8 to $10.0 \mathrm{x}$ by the same observer. The capillaries were classified in the following patterns: loop distribution, papilla, avascular fields, venous plexus, edema, form, capillary limbs, flow and hemorrhagic extravasation. The following capillary characteristics were considered normal: hairpin loop distribution, normal papilla, absent avascular fields, absent edema, normal form of capillary limbs, continuous flow and no hemorrhagic extravasation. Patients were classified in three groups according to pubertal status: prepubertal, spontaneous puberty and postpubertal, and also according to karyotype by $45, \mathrm{X}$ and mosaicism.

\section{Results}

Fifty patients with TS were studied, aged between 6-37 years. Patients' mean age was 17.2 \pm 4.0 . The karyotype of $27(54 \%)$ patients was 45,X and 23 (46\%) were mosaic. Sixteen (32\%) cases were prepubertal and 34 (68\%) were postpubertal. Spontaneous puberty occurred in six (12\%) patients and all continued to present regular menses.

Distribution of the presence of abnormalities by karyotype and pubertal status is presented in Table 1. Eighteen (36\%) patients had normal capillaroscopy in all patterns (group 1) and 32 (64\%) had abnormal capillaroscopy (group 2). Distribution of groups considering age and medication is presented in Table 2. Abnormality patterns are described in Tables 3 and 4 . Number of abnormality patterns varied among patients. Eleven $(22 \%)$ patients had only one abnormality, nine $(18 \%)$ had two, seven (14\%) had three, four ( $8 \%$ ) had four and one $(2 \%)$ had five abnormalities. All abnormalities are described in Table 5.

\section{Discussion}

Study of capillaries may express the status of vessel permeability and videocapillaroscopy is an easy and noninvasive method to study them. Since nailfold capillaries are parallel to the skin surface, they can be seen in 
Table 2 - Distribution of groups by age and medication

\begin{tabular}{|c|c|c|c|c|c|c|c|c|c|c|}
\hline \multirow[b]{2}{*}{ Age } & \multicolumn{5}{|c|}{ Group $1(n=18)$} & \multicolumn{5}{|c|}{ Group $2(n=32)$} \\
\hline & $\mathbf{N}$ & GH & $\mathbf{G H}+\mathbf{E}$ & $\mathbf{E}$ & $\mathbf{E}+\mathbf{P}$ & $\mathbf{N}$ & GH & $\mathbf{G H}+\mathbf{E}$ & $\mathbf{E}$ & $\mathbf{E}+\mathbf{P}$ \\
\hline $6-9$ & $1(100 \%)$ & $2(40 \%)$ & - & - & - & $\begin{array}{c}2 \\
(33.4 \%)\end{array}$ & $3(30 \%)$ & - & - & - \\
\hline $10-14$ & - & $3(60 \%)$ & - & - & - & $\begin{array}{c}2 \\
(33.3 \%)\end{array}$ & $5(50 \%)$ & - & - & - \\
\hline $15-19$ & - & - & $1(100 \%)$ & $2(100 \%)$ & $\begin{array}{c}4 \\
(44.5 \%)\end{array}$ & $\begin{array}{c}2 \\
(33.3 \%)\end{array}$ & $2(20 \%)$ & $1(100 \%)$ & - & $3(20 \%)$ \\
\hline $20-24$ & - & - & - & - & $\begin{array}{c}3 \\
(33.3 \%)\end{array}$ & - & - & - & - & $\begin{array}{c}4 \\
(26.7 \%)\end{array}$ \\
\hline $25-29$ & - & - & - & - & - & - & - & - & - & $6(40 \%)$ \\
\hline $30-34$ & - & - & - & - & $\begin{array}{c}2 \\
(22.2 \%)\end{array}$ & - & - & - & - & $1(6.6 \%)$ \\
\hline$>35$ & - & - & - & - & - & - & - & - & - & $1(6.7 \%)$ \\
\hline Total & 1 & 5 & 1 & 2 & 9 & 6 & 10 & 1 & - & 15 \\
\hline
\end{tabular}

$\mathrm{E}=$ estrogen therapy; $\mathrm{E}+\mathrm{P}=$ estrogen + progesterone therapy; $\mathrm{GH}=$ growth hormone therapy; $\mathrm{GH}+\mathrm{E}=$ growth hormone therapy + estrogen therapy; $\mathrm{N}=$ no medication.

Table 3 - Distribution of capillary patterns in group 2

\begin{tabular}{|c|c|c|}
\hline \multirow[b]{2}{*}{ Capillary pattern } & \multicolumn{2}{|c|}{ Group 2 - Abnormal $(n=32)$} \\
\hline & Normal & Abnormal \\
\hline Loops & Hairpin - 31 (96.8\%) & Mixed - $1(3.2 \%)$ \\
\hline \multirow[t]{2}{*}{ Papilla } & Normal - $15(46.9 \%)$ & Ratified - $13(40.6 \%)$ \\
\hline & & Enlarged - $4(12.5 \%)$ \\
\hline Avascular fields & Absent - $31(96.8 \%)$ & Present - $1(3.2 \%)$ \\
\hline Edema & Absent - $10(31.3 \%)$ & Present - $22(68.7 \%)$ \\
\hline \multirow[t]{2}{*}{ Form } & Normal - $26(81.2 \%)$ & Branched - $3(9.4 \%)$ \\
\hline & & Macrocapillaries - $3(9.4 \%)$ \\
\hline Capillary limbs & Normal - $27(84.4 \%)$ & Tortuosity - $5(15.6 \%)$ \\
\hline \multirow[t]{3}{*}{ Flow } & Continuous - 14 (43.8\%) & Fast - $7(21.9 \%)$ \\
\hline & & Granulous - $5(15.6 \%)$ \\
\hline & & Slow - $6(18.7 \%)$ \\
\hline Hemorrhagic extravasation & Absent - $31(96.8 \%)$ & Present - $1(3.2 \%)$ \\
\hline
\end{tabular}

full length by microscopy. This method only requires a period of about 20 days free of nailfold injuries. Cardiovascular complications are the main cause of increased mortality in TS. Ischemic heart disease risk factors reported in TS include hypertension, diabetes mellitus, dyslipidemia, obesity and estrogen deficiency. ${ }^{4,12,13}$ Capillaroscopy allows visibility of the capillaries but a single capillary form is not pathognomonic of a given disease. 


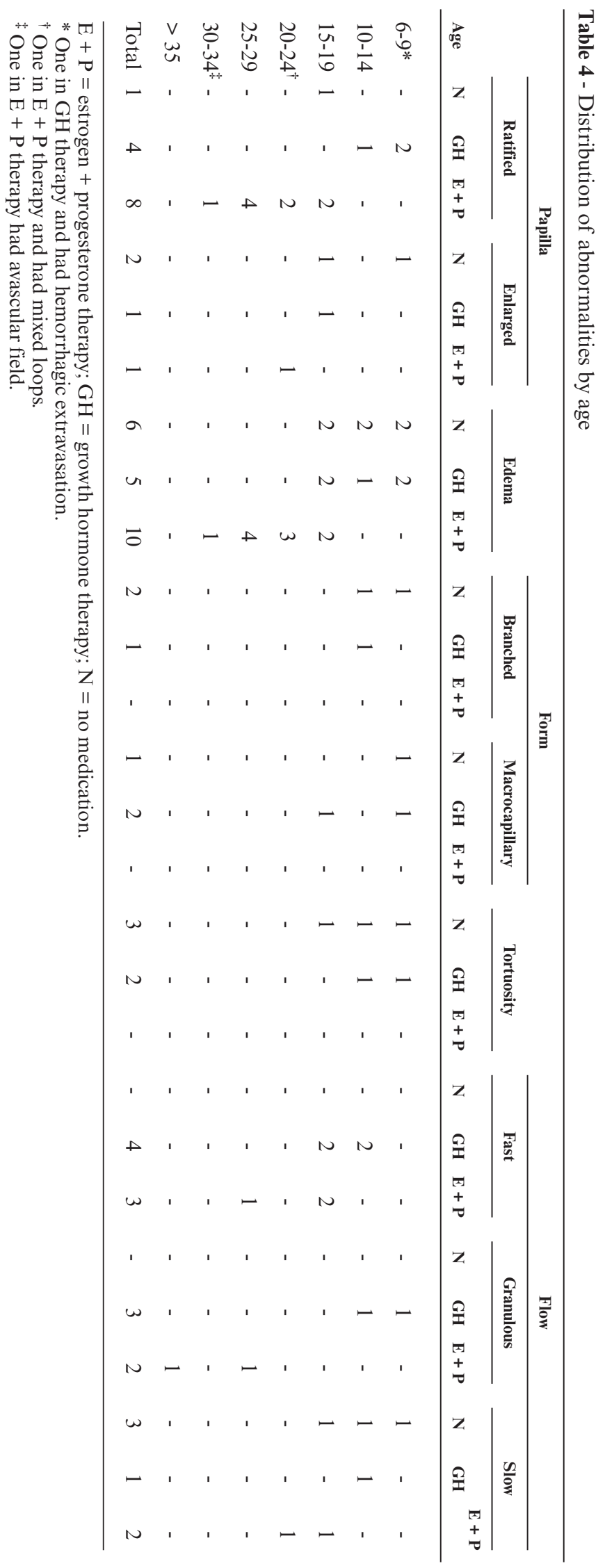




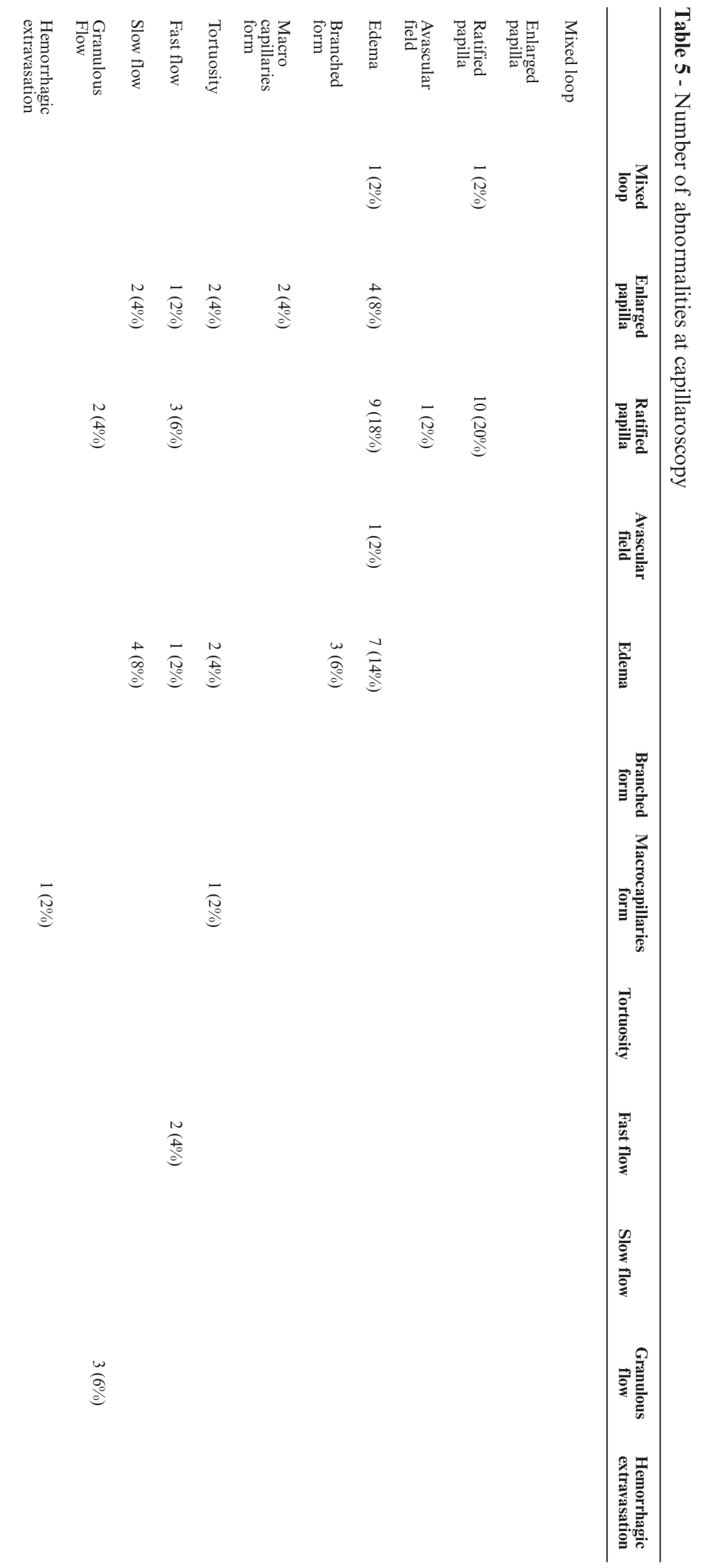


Hairpin pattern is considered normal ${ }^{18-21}$ and most cases in our study presented this form of loops. Some authors ${ }^{18,19}$ referred that presence of the venous plexus may be normal or not, considering patient's age. This occurs during childhood and it is reported that the plexus disappears in adults. Venous plexus was absent in almost $90 \%$ of the patients, but was present in three $(6 \%)$ adult patients. We are currently unable to define the significance of this presence. Tortuosity was present in $10 \%$ of cases. Leader ${ }^{18}$ considered that tortuosity may occur in adults, but any tortuosity must be considered abnormal in children. In our study, five patients had tortuosity. Two of them were children, prepubertal and using growth hormone and three were adolescents, without use of any medication and with development of spontaneous puberty. Diagnosis of tortuosity was performed using an article by Walls \& Buchanan, ${ }^{20}$ who consider tortuosity as being pathologic only if it is present in > $20 \%$ of capillaries studied. Tortuosity may represent diabetes ${ }^{24,25}$ or lupus erythematosus. ${ }^{26}$ Diabetes was an exclusion criterion of our research, and none of our patients presented symptoms or signs suggestive of lupus disease. Edema was the most common abnormality observed followed by ratified papilla, and the association of edema and ratified papilla occurred in about 16\% of the patients. Edema may represent trauma, especially in children, but it is not specific and is also reported in other pathologies, such as diabetes. ${ }^{27-29}$ We found edema in all ages and none of our patients indicated previous trauma. Trauma in children is more common than in other ages and may not be reported correctly as such by the child, whereas adolescents and adults may inform if there was any trauma event. Hands and fingers were examined before the nailfold capillaroscopy and none presented signs of injury.

Edema was observed mostly in older patients using estrogen and progesterone and in children using growth hormone, about 46 and 33\%, respectively. Growth hormone therapy is associated with some collateral effects, including edema and is also correlated to insulin resistance, which can deteriorate endothelial function. ${ }^{30}$ The same effect is reported with use of estrogens ${ }^{31}$ and the high prevalence found in this study may be explained by this collateral effect. On the other hand, estrogen receptors are present in vascular smooth muscle and endothelial cells and the use of estrogen therapy has a favorable effect on cardiovascular hemodynamics in TS. ${ }^{32,33}$ Chan et al. studied the effects of hormone replacement therapy on endothelial function in women with TS using plethysmography. These authors analyzed the endothelium-dependent vasodilator factors, such as bradykinin and endothelium-independent vasodilator factors, such as nitric oxide, and referred that hormone replacement therapy improved endothelial function in patients with TS. ${ }^{32}$ In the literature, it is reported that progesterone may antagonize the beneficial effect of estrogen on the vasculature. ${ }^{32}$ In our study, patients using only estrogen therapy or estrogen plus progesterone had a high prevalence $(18 \%)$ of edema and ratified papilla.

We found some cases with slow or granulous flow, which were abnormal and suggested some disturbance of the capillary circulation. ${ }^{19,21}$ Seven of our patients presented fast flow. There is no consensus about fast flow - some studies report this pattern to be normal, ${ }^{18}$ while others consider fast flow pathologic and associated with anemia. ${ }^{19}$ None of our patients had anemia. Presence of branched or macrocapillaries may indicate chronic diseases, such as dermatomyositis and sclerodemia. ${ }^{21,27,28}$ When these patterns are present, other pathologies should be investigated. The papilla was enlarged in four cases in this study and all of them also presented edema. Three group 2 patients had macrocapillaries, one of whom also had tortuosity. Moura et al. ${ }^{25}$ found that diabetic patients had more enlarged capillaries and tortuosity than the control group. This abnormality was also described in rheumatologic disease $\mathrm{e}^{21,28}$ and other studies have described hemorrhagic extravasation. ${ }^{21}$ In our study, only one patient presented hemorrhagic extravasation and needed to be evaluated for rheumatologic disease. We compared our data with reports for healthy subjects or in some diseases, such as diabetes or lupus erythematosus, ${ }^{24-26,29}$ because for TS we did not find previous reports about vascular endothelium using videocapillaroscopy. We conclude that there is a high prevalence of alterations in nailfold capillaroscopy in TS and that edema and ratified papilla are the main alterations.

\section{References}

1. Turner HH. A syndrome of infantilism, congenital webbed neck and cubitus valgus. Endocrinology. 1938;23:566-74. 
2. Ranke MB, Saenger P. Turner's syndrome. Lancet. 2001;358:309-14.

3. Battin J. Syndrome de Turner et mosaïcisme. Bull Acad Natle Med. 2003;187:359-71.

4. Saenger P, Wikland KA, Conway GS, et al. Recommendations for the diagnosis and management of Turner syndrome. J Clin Endocrinol Metab. 2001;86:3061-9.

5. Elseheikh M, Dunger DB, Conway GS, Wass JA. Turner's syndrome in adulthood. Endocrine Rev. 2002;23:120-40.

6. Frías JL, Davenport ML. Health supervision for children with Turner syndrome Pediatrics. 2003;111:692-702.

7. Bakalov VK, Cooley MM, Quon MJ, et al. Impaired insulin secretion in the Turner syndrome. J Clin Endocrinol Metab. 2004;89:3516-20.

8. Caprio S, Boulware S, Diamond M, et al. Insulin resistance: an early metabolic defect of Turner's syndrome. J Clin Endocrinol Metab. 1991;72:832-6.

9. Gravholt CH. Epidemiological, endocrine and metabolic features in Turner syndrome. Eur J Endocrinol. 2004;151:657-87.

10. Salgin B, Amin R, Yuen K, et al. Insulin resistance is an intrinsic defect independent of fat mass in women with Turner syndrome. Horm Res. 2005;65:69-75.

11. Choi IK, Kim DH, Kim HS. The abnormalities of carbohydrate metabolism in Turner syndrome: analysis of risk factors associated with impaired glucose tolerance. Eur J Pediatr. 2005;164:442-7.

12. Gravholt CH, Naeraa RW, Nyholm B, et al. Glucose metabolism, lipid metabolism and cardiovascular risk factors in adult Turner's syndrome: the impact of sex hormone replacement. Diabetes Care. 1998;21:1062-70.

13. Stoppoloni G, Prisco F, Alfano C, Iafusco D, Marrazzo G, Paolisso G. Characteristics of insulin resistance in Turner syndrome. Diabete Metab. 1990;6:267-71.

14. Matthews DR, Hosker JP, Rudenski AS, Naylor BA, Treacher DF, Turner RC. Homeostasis model assessment: insulin resistance and B-cell function from fasting glucose and insulin concentrations in man. Diabetologia. 1985;28:412-9.

15. Tooke JE, Hannemann MM. Adverse endothelial function and the insulin resistance syndrome. J Intern Med. 2000;247:425-31.

16. Wallace TM, Matthews DR. The assessment of insulin resistance in man. Diabet Med. 2002;19:527-34.

17. Gravholt CH, Nyholm B, Saltin B, Schmitz O, Christiansen JS. Muscle fiber composition and capillary density in Turner syndrome. Diabetes Care. 2001;24:1668-73.

18. Leader SD. Capillary microscopy in children. Am J Dis Child. 1932;44:403-16.

19. Mayer KM. Observations on the capillaries of the normal infant. Am J Dis Child. 1921;22:381-7.

20. Walls EW, Buchanan TJ. Observations on the capillary blood vessels of the human nail fold. J Anat. 1956;90:329-36.
21. Cony M, Boudard CK, Fontan I, et al. Etude des aspects capillaroscopiques péri-unguéaux chez l'enfant normal. Arch Fr Pediatr. 1992;49:171-4.

22. Halfoun VL, Pires ML, Fernandes TJ, Victer F, Rodrigues KK, Tavares RT. Videocapillaroscopy and diabetes mellitus: area of transverse segment in nailfold capillary loops reflects vascular reactivity. Diabetes Res Clin Pract. 2003;61:155-60.

23. Bosley PG, Gibson WC, Griffiths RS. Photomicrographic capillary networks in human control subjects. J Nerv Ment Dis. 1956;123:219-31.

24. Moura CC, Moura EG, Bouskela E, Torres Filho IP, Breintenbach MM. Nailfold capillaroscopy in diabetes mellitus: morphological abnormalities. J Vasc Med Biol. 1990;2:52-5.

25. Moura CC, Moura EG, Bouskella E, Torres Filho IP, Breintenbach MM. Nailfold capillaroscopy in diabetes mellitus: morphological abnormalities and relationship with microangiopathy. Braz J Med Biol Res. 1987;20:777-80.

26. Buchanan IS, Humpston DJ. Nailfold capillaries in connective-tissue disorders. Lancet. 1968;1:845-7.

27. Ditzel J. Morphologic and hemodynamic changes in the smaller blood vessels in Diabetes mellitus I. Considerations based on literature. N Engl J Med. 1954;250:541-6.

28. Maricq HR, Le Roy EC, D’Angelo WA, et al. Diagnostic potential of in vivo capillary microscopy in scleroderma and related disorders. Arthritis Rheum. 1980;23:183-8.

29. Dancour MA, Vaz JL, Bottino DA, Bouskela E. Nailfold videocapillaroscopy in patients with systemic lupus erythematosus. Rheumatol Int. 2006;26:633-7.

30. Bowbly DA, Rapaport R. Safety and efficacy of growth hormone therapy in childhood. Pediatr Endocrinol Rev. 2004;2(Suppl 1):68-77.

31. Wygoda MM, Fillipo Jr RR, Gomes MAS, Clapauch R. Monitorizando a terapia de reposição estrogênica (TRE) na menopausa. Arq Bras Endocrinol Metab. 1999;43:336-43.

32. Elsheikh M, Bird R, Casadei B, Conway GS, Wass JA. The effect of hormone replacement therapy on cardiovascular hemodynamics in women with Turner's syndrome. J Clin Endocrinol Metab. 2000;85:614-8.

33. Chan NN, Vallance P, Colhoun HM, MacAllister J, Hingorani AD, Conway GS. The effects of hormone replacement therapy on endothelial function in women with Turner's syndrome. Clin Endocrinol. 2002;56:615-20.

Correspondence:

Simone C S Coelho

Rua Castro Alves, 74/101, Méier

CEP 20775-040 - Rio de Janeiro, RJ - Brazil

Tel.: +55 (21) $2281.7247,+55$ (21) 8136.5422

E-mail: adilcoel@oi.com.br 